\title{
Special Issue on Disasters and Long Term Recovery
}

\author{
F. Richard Ferraro ${ }^{1}$
}

Published online: 15 August 2015

(C) Springer Science+Business Media New York 2015

It is with great pleasure that I introduce the First Special Issue for Current Psychology as Editor-in-Chief. This Special Issue, dealing with the psychological aftermath of a decade of disasters is in exceptional hands and I am happy to see Katie Cherry, Ph.D. at the helm of this Special Issue. Katie and I go back a long way. We both did dissertations on adult development and aging and routinely attend the biennial Cognitive Aging Conference in Atlanta. Katie is already an established expert in the field of Cognitive Aging with more recent work in Disasters and Aging, having published widely in each area. She now adds to this impressive list of research on the impact (short- as well as long-term) of the 2005 Hurricanes Katrina and Rita and the 2010 BP Oil Spill. I hope you enjoy these impressive papers as much as I do.

F. Richard Ferraro

f.richard.ferraro@EMAIL.UND.EDU

1 University of North Dakota, Grand Forks, ND, USA 